\title{
Review of the Economic and Ethnobotany of the Family Nyctaginaceae
}

\author{
Miriam Kritzer Van Zant
}

Department of Plant, Soil and Agricultural Systems, Southern Illinois University, Carbondale, IL 62901-4415, USA

Received: April 9, 2016 / Accepted: May 25, 2016

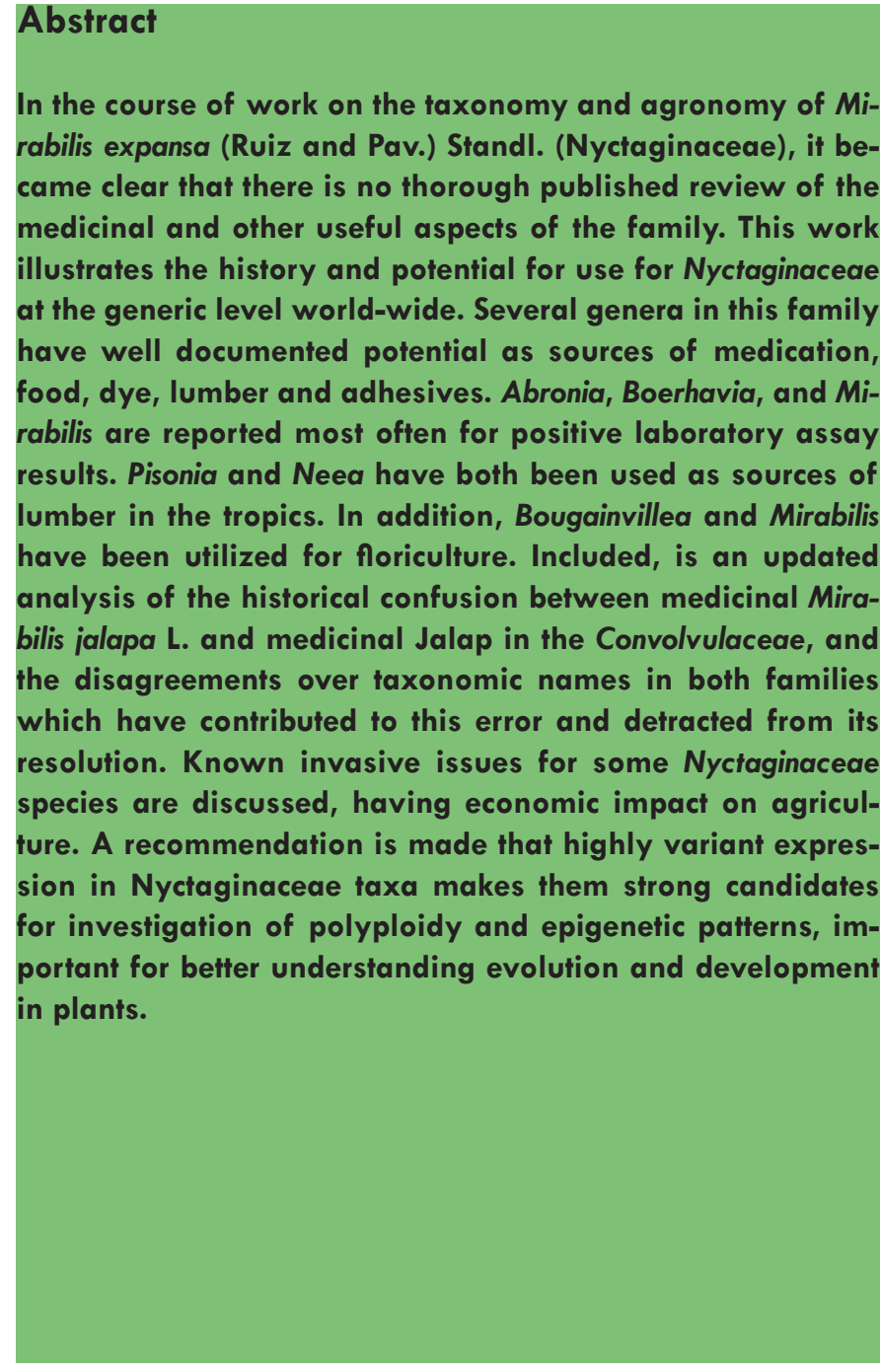

* Corresponding author: mkvzant@siu.edu

\section{Introduction}

This is primarily a genus level overview of the economic and ethnobotany of the Nyctaginaceae. Details are only presented sufficiently to fill the void for a published world-wide look at the uses of the family. Most of these uses were originally presented for particular species, growing in specific locations, in the literature. A separate review of the genus Mirabilis, with species specific ethnobotanical and agricultural information primarily for M. expansa has been published as a separate paper (2016b) modified from Kritzer Van Zant's dissertation (2016a). Asterisks next to source names below, indicate that they were mentioned in a secondary reference, and have not been directly evaluated by this author. There are four tables included of information summarized from the literature. They are: Table 1. Medicinal use of Nyctaginaceae genera - anecdotal reports; Table 2. Food and forage uses of Nyctaginaceae genera - anecdotal reports; Table 3. Lumber, floriculture and other uses of Nyctaginaceae genera - anecdotal reports; and Table 4. Nyctaginaceae genera - results of laboratory analyses.

\section{Methods}

Book chapters, articles and journals obtained through library and on-line sources, and a NAPRALERT (Natural Products Alert Database) print out on the Nyctaginaceae from the University of Illinois-Chicago, were analyzed and summarized. NAPRALERT uses its own standard coding for cross-comparing most of the data presented. However, ethnobotanical information is presented in each of the four tables by genus then source, as it was unclear to us if some seemingly technical terms were always used the same way among authors. There may be repetition among authors for some of the same reports of use. Which were replicated and which were original could not be readily teased apart. Therefore, they were left in the tables as is. Also,
ATLOS Publishing, LP
This is an Open Access article distributed under the terms of the Creative Commons Attribution License (http://creativecommons.org/licenses/by/3.0/), which permits unrestricted use, distribution, and reproduction in any medium, provided the original work is properly cited. 
Table 1. Medicinal use of Nyctaginaceae genera* -anecdotal reports.

\begin{tabular}{|c|c|c|c|c|c|c|}
\hline Use & Genus & Plant Part & Preparation & Tribe & Location & Source \\
\hline purgative & Boerhavia & & & & Peru & Ruiz (1777-1788, 1940) \\
\hline against venereal & Boerhavia & & & & Peru & Ruiz (1777-1788, 1940) \\
\hline infections & Nyctaginaceae & & & & & \\
\hline purgative & Boerhavia & roots & & & Malaysia & Bogle (1974) \\
\hline anthelmintic & Boerhavia & roots & & & Malaysia & Bogle (1974) \\
\hline febrifuge & Boerhavia & roots & & & Malaysia & Bogle (1974) \\
\hline asthma & Boerhavia & leaves & liquid extract & & S America & Bogle (1974) \\
\hline jaundice & Boerhavia & leaves & liquid extract & & S America & Bogle (1974) \\
\hline diuretic & Boerhavia & leaves & & & S America & Bogle (1974) \\
\hline emetic & Boerhavia & leaves & & & S America & Bogle (1974) \\
\hline expectorant & Boerhavia & leaves & & & S America & Bogle (1974) \\
\hline headaches & Boerhavia & & & & Argentina & NAPRALERT (1998) \\
\hline diuretic & Boerhavia & & & & Argentina & NAPRALERT (1998) \\
\hline antipyretic & Boerhavia & & & & Argentina & NAPRALERT ( 1998) \\
\hline urinary inflammations & Boerhavia & & & & Bolivia & NAPRALERT ( 1998) \\
\hline galactogogue & Boerhavia & & & & Bolivia & NAPRALERT (1998) \\
\hline childbirth, difficult & Boerhavia & & & & Guinea-Bissau & NAPRALERT (1998) \\
\hline diuretic & Boerhavia & & & & India & NAPRALERT (1998) \\
\hline jaundice & Boerhavia & & & & India & NAPRALERT (1998) \\
\hline anti-inflammatory & Boerhavia & & & & India & NAPRALERT (1998) \\
\hline cataracts & Boerhavia & & eye drops & & India & NAPRALERT (1998) \\
\hline febrifuge & Boerhavia & & & & Nigeria & NAPRALERT ( 1998) \\
\hline $\begin{array}{l}\text { laxative, mild for } \\
\text { children }\end{array}$ & Boerhavia & & & & Nigeria & NAPRALERT (1998) \\
\hline anti-asthmatic & Boerhavia & & & & Nigeria & NAPRALERT (1998) \\
\hline anti-convulsant & Boerhavia & & & & Nigeria & NAPRALERT (1998) \\
\hline expectorant & Boerhavia & & & & Nigeria & NAPRALERT (1998) \\
\hline emetic & Boerhavia & & & & Nigeria & NAPRALERT (1998) \\
\hline menstruation, regulate & Boerhavia & & & & West Africa & NAPRALERT (1998) \\
\hline abortifacient & Boerhavia & & & & West Africa & NAPRALERT (1998) \\
\hline diuretic & Boerhavia & & & & India & NAPRALERT (1998) \\
\hline dropsy, to treat & Boerhavia & & & & India & NAPRALERT (1998) \\
\hline edema & Boerhavia & & & & India & NAPRALERT (1998) \\
\hline anemia & Boerhavia & & & & India & NAPRALERT (1998) \\
\hline jaundice & Boerhavia & & & & India & NAPRALERT (1998) \\
\hline menstrual problems & Boerhavia & & & & India & NAPRALERT (1998) \\
\hline heart disease & Boerhavia & & & & India & NAPRALERT (1998) \\
\hline emetic & Boerhavia & & & & India & NAPRALERT (1998) \\
\hline stomachic & Boerhavia & & & & India & NAPRALERT (1998) \\
\hline laxative & Boerhavia & & & & India & NAPRALERT (1998) \\
\hline diuretic & Boerhavia & & & & Iran & NAPRALERT (1998) \\
\hline
\end{tabular}

rearrangement even of NAPRALERT data saves little space, as instead of repeating technical terms for each location, it would have been necessary to repeat each location for each technical term. As previously mentioned, asterisks are used to mark dates given by other authors, for literature we have not examined first hand. As all of the information is in the tables, we grouped comments together as appropriate in the text. Included below is an analysis of taxonomic problems involved in the confusion over M. jalapa and medicinal Jalap in the Convolvulaceae, for which many sources were used including the on-line IPNI (Internation- al Plant Names Index) database maintained by Royal Botanic Gardens, Kew.

Briefly mentioned below are both unpublished amino acid percentage profiles and negative cytotoxicity data for two $M$. expansa horticultural varieties originally from Peru and Ecuador, grown in sand plots in southern Illinois (Kritzer Van Zant, 2016a). The cancer cell cytotoxicity assay was executed by Hee-Byung Chai (Kritzer Van Zant, 2016a) in Douglas Kinghorn's lab at Ohio State University. Methanol extracts of both horticultural varieties were utilized in the assay, made by this author in labo- 
Table 1. Continued.

\begin{tabular}{|c|c|c|c|c|c|c|}
\hline Use & Genus & Plant Part & Preparation & Tribe & Location & Source \\
\hline gonorrhea, for treating & Boerhavia & & & & Iran & NAPRALERT (1998) \\
\hline nephritis & Boerhavia & & & & Iran & NAPRALERT (1998) \\
\hline edema & Boerhavia & & & & Iran & NAPRALERT (1998) \\
\hline joint pain & Boerhavia & & & & Iran & NAPRALERT (1998) \\
\hline appetite stimulant & Boerhavia & & & & Iran & NAPRALERT (1998) \\
\hline aphrodisiac & Boerhavia & & & & New Guinea & NAPRALERT (1998) \\
\hline sterility, to induce & Boerhavia & & & & New Guinea & NAPRALERT (1998) \\
\hline hepatitis, to treat & Bougainvillea & & & & Taiwan & NAPRALERT (1998) \\
\hline cuts and sores, to heal & Commicarpus & & & & Bahamas & NAPRALERT (1998) \\
\hline laxative, mild & Mirabilis & & & & Peru & Ruiz (1777-1788, 1940) \\
\hline purgative, mild & Mirabilis & & & & & Bogle (1974) \\
\hline dropsy, to treat & Mirabilis & & & & & Bogle (1974) \\
\hline poultices, to make & Mirabilis & & & & & Bogle (1974) \\
\hline boils, to treat & Mirabilis & & & & & Bogle (1974) \\
\hline abscesses, to treat & Mirabilis & & & & & Bogle (1974) \\
\hline scabies, to treat & Mirabilis & & & & & Bogle (1974) \\
\hline jalap source & Mirabilis & roots & resin & & Pacific islands & Walker (1976) \\
\hline purgative & Mirabilis & roots & & & & Cabieses (1995) \\
\hline diuretic & Mirabilis & roots & & & Peru & NAPRALERT (1998) \\
\hline diuretic & Mirabilis & roots & & & West Indies & NAPRALERT (1998) \\
\hline herpes, to treat & Neea & & & & Cuba & NAPRALERT (1998) \\
\hline tooth decay prevention & Neea & leaves & chewed & & Peru & NAPRALERT (1998) \\
\hline tooth decay prevention & Neea & leaves & chewed & & Columbia & NAPRALERT (1998) \\
\hline $\begin{array}{l}\text { rheumatic disease, to } \\
\text { treat }\end{array}$ & Pisonia & leaves & decoction & & Jamaica & Bogle (1974) \\
\hline $\begin{array}{l}\text { venereal disease, to } \\
\text { treat }\end{array}$ & Pisonia & leaves & decoction & & Jamaica & Bogle (1974) \\
\hline $\begin{array}{l}\text { rheumatic disease, to } \\
\text { treat }\end{array}$ & Pisonia & leaves & decoction & & Yucatan & Bogle (1974) \\
\hline $\begin{array}{l}\text { venereal disease, to } \\
\text { treat }\end{array}$ & Pisonia & leaves & decoction & & Yucatan & Bogle (1974) \\
\hline fevers, to treat & Pisonia & fruits & & & Mexico & Bogle (1974) \\
\hline dysentary, to treat & Pisonia & & & & Rotuma & NAPRALERT (1998) \\
\hline diuretic & Abronia & & & Diegueño & California & Strike (1994) \\
\hline lactation, increase & Abronia & & & & Mexico & NAPRALERT (1998) \\
\hline fever, to treat & Allionia & & & Teton Dakota & Missouri River region & Gilmore $(1914 *, 1919 *, 1977)$ \\
\hline
\end{tabular}

ratories at Southern Illinois University-Carbondale. This negative cytotoxicity data, together with the specificity of published positive and negative anti-microbial data summarized below, indicate that there is unlikely to be a broad spectrum toxic micromolecule in the southern Illinois grown $M$. expansa horticultural varieties. It should be noted that this kind of methanol extraction retains micro-molecules, though proteins are destroyed in the process.

Protein extracts from roots of $M$. expansa were found to have specific toxicity via a Class I ribosome inhibitor, against certain species of soil fungi, in a series of publications by Vivanco and colleagues, specified below. Class I ribosome inhibitors are not known to affect humans (J.M. Vivanco, personal communication, 2008). Names, for the horticultural varieties of M. expansa from which data for the field and nutrition chapters in Kritzer Van
Zant (2016a) were taken, will be detailed in taxonomic papers also in preparation, including morphological keys and descriptions. These taxonomic papers await completion of analysis of the considerable and notoriously confusing contradictions for synonyms in the family, which has taken several years to clarify. These new assay results are mentioned below, in the overall look at laboratory assay results for the family, along with nutritional information concerning amino acids in $M$. expansa from assays done in collaboration with Bill Banz at SIU-C (Kritzer Van Zant, $2016 a$ ). Details on how the extractions were made, and the results of the assays executed by Dr. Chai are also given in Kritzer Van Zant (2016a). The unpublished taxonomic research on the Mirabilis complex in the Andes is the basis of acceptance of $M$. expansa (Ruiz and Pav.) Standl., as the correct species name for both the wild type and crop. Earlier peer reviewed publications 
Table 1. Continued.

\begin{tabular}{|c|c|c|c|c|c|c|}
\hline Use & Genus & Plant Part & Preparation & Tribe & Location & Source \\
\hline vermifuge & Allionia & & combined w/ Echinacea spp. & Oglala & Missouri River region & Gilmore $\left(1914^{*}, 1919^{*}, 1977\right)$ \\
\hline $\begin{array}{l}\text { swelling reduction, arms and } \\
\text { legs }\end{array}$ & Allionia & roots & rub & & Missouri River region & Gilmore $\left(1914^{*}, 1919^{*}, 1977\right)$ \\
\hline wounds, to treat & Allionia & & externally & Ponka & Missouri River region & Gilmore $\left(1914^{*}, 1919^{*}, 1977\right)$ \\
\hline $\begin{array}{l}\text { sore mouths, to treat in } \\
\text { babies }\end{array}$ & Allionia & roots & dry powdered & Pawnee & Missouri River region & Gilmore $\left(1914 *, 1919^{*}, 1977\right)$ \\
\hline coughs, to treat & Bougainvillea & & & & Mexico & NAPRALERT (1998) \\
\hline $\begin{array}{l}\text { sprains and swelling, to } \\
\text { reduce }\end{array}$ & Mirabilis & & & Ojibwe & & Smith (1932) \\
\hline swelling reduction & Mirabilis & & & Ojibwa & & King (1984) \\
\hline fever, to treat & Mirabilis & & & Missouri River region tribes & & King (1984) \\
\hline worms, to treat & Mirabilis & & & Missouri River region tribes & & King (1984) \\
\hline swellings, to treat & Mirabilis & & & Missouri River region tribes & & King (1984) \\
\hline $\begin{array}{l}\text { to keep new born babies } \\
\text { healthy }\end{array}$ & Mirabilis & & decoction & Karok & California & Strike (1994) \\
\hline purgative & Mirabilis & & decoction & Lusieño & California & Strike (1994) \\
\hline stomach aches, to treat & Mirabilis & & decoction & Kumeyaay & California & Strike (1994) \\
\hline $\begin{array}{l}\text { lesions -dermato-mucosal, } \\
\text { to treat }\end{array}$ & Neea & & & & Guatemala & NAPRALERT (1998) \\
\hline
\end{tabular}

on the crop also use the name $M$. expansa, and describe cultivars. However, these publications lack Latin names for horticultural varieties. Results from the literature are summarized from the tables, in the text.

\section{Results}

\section{Anecdotal Reports of Use of the Nyctaginaceae -General Informa- tion.}

Ruiz and Pavon, who first named M. expansa, collected with French botanist Dombey to carry through the first crown commissioned botanical expedition for Spain in South America. Both Ruiz and Pavon were primarily trained in Spain as pharmacists, reflected in their collections and publications. Ruiz' anecdotal reports from the late 1700s, on the economic uses of Nyctaginaceae taxa in South America, are included in this section along with reports from several later authors. Gunther (1945) attributed information to Stuhr (1933*) and Haskins (1934*). Bogle
(1974) summarized information on use of Mirabilis from Bailey \& Bailey $\left(1941^{*}\right)$, Chittenden (1965*), Stemmerik (1964), and Uphof $\left(1968^{*}\right)$. Bogle (1974) states that in general, the Nyctaginaceae have little economic value, except for widely cultivated species of Abronia, Mirabilis, and Bougainvillea, and less commonly cultivated Boerhavia and Pisonia. Bogle (1974) provides information on economic uses for Mirabilis, Boerhavia, and Pisonia. Bogle seems to have used a narrow interpretation of economic value, perhaps he was referring to reported value as cash crops. NAPRALERT (1998) has summarized numerous world-wide anecdotal reports for use of the Nyctaginaceae. Many of the more notable reports of use from NAPRALERT come from the equatorial region. North American anecdotal use from NAPRALERT is also covered in the anecdotal sections, followed by another section containing the results of laboratory assays reported from NAPRALERT and other sources. Anecdotal information on use of Nyctaginaceae genera by Native Americans is also included in Tables 1 through 3 from Moerman (1998) though only at the family level, as Moerman is both extensive 
Table 1. Continued.

\begin{tabular}{|c|c|c|c|c|c|c|}
\hline Use & Genus & Plant Part & Preparation & Tribe & Location & Source \\
\hline diabetes, to treat & Salpianthus & & & & Mexico & NAPRALERT (1998) \\
\hline sedatives for children & Nyctaginaceae & & & Nat Am & $\mathrm{NAm}$ & Moerman (1998) \\
\hline headaches, to treat & Nyctaginaceae & & & Nat Am & N Am & Moerman (1998) \\
\hline neuralgia & Nyctaginaceae & & & Nat Am & $\mathrm{N} \mathrm{Am}$ & Moerman (1998) \\
\hline delirium & Nyctaginaceae & & & Nat Am & N Am & Moerman (1998) \\
\hline dizziness & Nyctaginaceae & & & Nat Am & $\mathrm{NAm}$ & Moerman (1998) \\
\hline fainting & Nyctaginaceae & & & Nat Am & $\mathrm{NAm}$ & Moerman (1998) \\
\hline boils, to treat & Nyctaginaceae & & & Nat Am & N Am & Moerman (1998) \\
\hline spider and insect bites & Nyctaginaceae & & & Nat Am & N Am & Moerman (1998) \\
\hline astringent & Nyctaginaceae & & & Nat Am & $\mathrm{NAm}$ & Moerman (1998) \\
\hline poultice to treat burns & Nyctaginaceae & & & Nat Am & N Am & Moerman (1998) \\
\hline swellings, to treat & Nyctaginaceae & & & Nat Am & $\mathrm{NAm}$ & Moerman (1998) \\
\hline sores & Nyctaginaceae & & & Nat Am & N Am & Moerman (1998) \\
\hline sore mouth & Nyctaginaceae & & & Nat Am & $\mathrm{N} \mathrm{Am}$ & Moerman (1998) \\
\hline perspiring feet & Nyctaginaceae & & bath & Nat Am & N Am & Moerman (1998) \\
\hline bruises, to apply to & Nyctaginaceae & & & Nat Am & N Am & Moerman (1998) \\
\hline sprains, to apply to & Nyctaginaceae & & & Nat Am & $\mathrm{N} \mathrm{Am}$ & Moerman (1998) \\
\hline broken bones, to apply to & Nyctaginaceae & & & Nat Am & $\mathrm{N} \mathrm{Am}$ & Moerman (1998) \\
\hline dandruff & Nyctaginaceae & & as a shampoo & Nat Am & $\mathrm{NAm}$ & Moerman (1998) \\
\hline snake bite treatment & Nyctaginaceae & & steam bath & Nat Am & N Am & Moerman (1998) \\
\hline appetite, increase & Nyctaginaceae & & internal & Nat Am & $\mathrm{NAm}$ & Moerman (1998) \\
\hline appetite, control & Nyctaginaceae & & internal & Nat Am & $\mathrm{N} \mathrm{Am}$ & Moerman (1998) \\
\hline $\begin{array}{l}\text { effects of swallowing a } \\
\text { spider, to neutralize }\end{array}$ & Nyctaginaceae & & & Nat Am & $\mathrm{NAm}$ & Moerman (1998) \\
\hline cathartic & Nyctaginaceae & & & Nat Am & $\mathrm{NAm}$ & Moerman (1998) \\
\hline sudorific & Nyctaginaceae & & & Nat Am & N Am & Moerman (1998) \\
\hline emetic & Nyctaginaceae & & & Nat Am & $\mathrm{N} \mathrm{Am}$ & Moerman (1998) \\
\hline diuretic & Nyctaginaceae & & & Nat Am & $\mathrm{NAm}$ & Moerman (1998) \\
\hline purgative & Nyctaginaceae & & & Nat Am & $\mathrm{NAm}$ & Moerman (1998) \\
\hline febrifuge for eruptive fevers & Nyctaginaceae & & & Nat Am & N Am & Moerman (1998) \\
\hline stomach cramps & Nyctaginaceae & & & Nat Am & $\mathrm{NAm}$ & Moerman (1998) \\
\hline stomach disorders & Nyctaginaceae & & & Nat Am & N Am & Moerman (1998) \\
\hline
\end{tabular}

and relatively easy to obtain. Moerman (1998) summarized reported use by North American indigenous tribes, of many species in the genera Abronia (which includes Tripterocalyx), Allionia, Boerhavia, and Mirabilis. Inclusion of Moerman (1998) demonstrates that widespread use of the family was not limited to the southern hemisphere and tropical countries.

\section{Anecdotal Reports of Medicinal Use of the Nyctaginaceae}

Medicinal uses of Nyctaginaceae genera - anecdotal reports (Table 1) includes information from Ruiz (1777-1788 (1940), Gilmore (1914*, 1919*, 1977), Smith (1932), Bogle (1974), Hamel and Chiltoskey (1975), Walker (1976), King (1984), Meeker et al. (1993), Pelayo-Benavides and Anaya (1993), Strike (1994), Cabieses (1995), and NAPRALERT (1998), in addition to family level information summarized from Moerman (1998).

For Abronia, anecdotal reports of medicinal use are attributed to the Diegueño tribe in California, and to Mexico. Abronia has been reported anecdotally for medicinal use as a diuretic and to increase lactation (Table 1). Moerman (1998) summarized reported use by North American indigenous tribes, of many species in the genera Abronia, which includes Tripterocalyx. Information on Tripterocalyx is included at the family level below and in our tables, and is not distinguished here from Abronia.

For Allionia, anecdotal reports of medicinal use are attributed to the Missouri River region of the United States, and some uses are specified to the Pawnee, Teton Dakota, Oglala and Ponka tribes (Table 1). Specifics, when given, are only for preparation from Allionia roots. Allionia has been reported anecdotally for medicinal use to reduce abdominal swelling after childbirth, to treat fevers, sore mouths in babies, for reduction of swelling of arms and legs, as a vermifuge, and to treat wounds (Table 1). Gilmore (1914*, 1919*, 1977) reports Allionia was combined with Echinacea spp. by the Teton Dakota. Gilmore also seems to refer to the same combination of plants as used by the Oglala as a vermifuge, stating that the Oglala decoction will even expel large tapeworms. 
Table 1. Continued.

\begin{tabular}{|c|c|c|c|c|c|c|}
\hline Use & Genus & Plant Part & Preparation & Tribe & Location & Source \\
\hline fainting spells & Nyctaginaceae & & & Nat Am & N Am & Moerman (1998) \\
\hline nausea & Nyctaginaceae & & & Nat Am & $\mathrm{N} \mathrm{Am}$ & Moerman (1998) \\
\hline \multicolumn{6}{|l|}{ veterinary } & Moerman (1998) \\
\hline bladder problems & Nyctaginaceae & & & Nat Am & $\mathrm{NAm}$ & Moerman (1998) \\
\hline \multicolumn{6}{|l|}{ support } & Moerman (1998) \\
\hline vermifuge & Nyctaginaceae & & & Nat Am & $\mathrm{NAm}$ & Moerman (1998) \\
\hline snake bite & Nyctaginaceae & & & Nat Am & $\mathrm{NAm}$ & Moerman (1998) \\
\hline \multicolumn{7}{|l|}{$\begin{array}{l}\text { particularly in the } \\
\text { throat }\end{array}$} \\
\hline $\begin{array}{l}\text { post-partum } \\
\text { treatment }\end{array}$ & \multicolumn{5}{|c|}{ treatment } & Moerman (1998) \\
\hline laxative & Mirabilis & & & & & $\begin{array}{l}\text { Pelayo-Benavidez } \\
\text { and Anaya (1993) }\end{array}$ \\
\hline \multicolumn{7}{|c|}{$\begin{array}{l}\text {-Moerman (1998) is only cited here at the family level. As for all of the authors most information given at the genus level is available at the spp. level in the } \\
\text { original source. }\end{array}$} \\
\hline \multicolumn{7}{|c|}{$\begin{array}{l}\text {-Although some categories of use probably overlap, they were not compiled further as their exact meaning may have slightly different definitions in different } \\
\text { sources. } \\
\text {-An attempt was made to set up the coding of use so that similar descriptions of use would sort in succession, though this was not always possible. }\end{array}$} \\
\hline
\end{tabular}

For Boerhavia, anecdotal reports of medicinal use are attributed to Argentina, Bolivia Peru, South America, India, Iran, Malaysia, Guinea-Bissau, Nigeria, and West Africa (Table 1). Both roots and leaves of Boerhavia have been specified as used in medicinal preparations. Boerhavia has been reported anecdotally for medicinal use as an abortifacient, against venereal infections and anemia, as an anthelmintic, anti-asthmatic, anticonvulsant, anti-inflammatory, antipyretic, aphrodisiac, appetite stimulant, to treat asthma, cataracts, difficult childbirth, as a diuretic, to treat dropsy and edema, as an emetic, expectorant, febrifuge, galactogogue, to treat gonorrhea, headaches, heart disease, jaundice, joint pain, as a laxative mild enough for children, to address menstrual problems including regulation of menstruation, to treat nephritis, as a purgative, to induce sterility, as a stomachic, and to treat urinary inflammations (Table 1). Bougainvillea has been used medicinally in Taiwan for treating hepatitis (Table 1). Commicarpus has been used in the Bahamas to heal cuts and sores (Table 1).

For Mirabilis, anecdotal reports of medicinal use are attributed to Peru, the West Indies, Pacific islands, and California in the United States (Table 1). Mostly roots and the whole plant have been specified for Mirabilis as used in medicinal preparation. Mirabilis has been reported anecdotally for medicinal use to treat abscesses, bladder problems, boils, as a diuretic, to treat dropsy, fever, as a source of jalap (see discussion on jalap below), as a laxative also specified as mild, for treating strained muscles, boils, to make poultices, as a purgative sometimes specified as mild, to treat scabies, to reduce sprains and swellings, to treat stomach aches, to keep new born babies healthy and for worms (Table 1). Calyxhymenia and Oxybaphus were included by us as Mirabilis (Table 1). Oxybaphus was reported separately from Mirabilis by King (1984) and Smith (1932). King (1984) based her report on Mirabilis nyctaginea (Michx.) MacMill. on information from Densmore 1928*, Gilmore 1919*, and Smith 1928* and 1932. King gives Oxybaphus nyctaginea (Michx.) Sweet as a synonym for M. nyctaginea, and says the plant is common in waste areas in Illinois and introduced. However, Gleason and Cronquist (1991) separate M. nyctaginea's native range, including Illinois, from where it has since established in the eastern United States.

For Neea, anecdotal reports of medicinal use are attributed to Columbia, Peru, Guatemala and Cuba (Table 1). Only leaves of Neea have been specified as used in medicinal preparation where reported. Neea has been reported anecdotally for medicinal use to treat fungal diseases, gonorrhea, herpes, dermatomucosal lesions, ringworm, and leaves are chewed to prevent tooth decay (Table 1).

For Pisonia, anecdotal reports of medicinal use are attributed to Jamaica, Yucatan, Mexico and Rotuma (Table 1). Leaves and fruits of Pisonia have been specified as used in medicinal prepa- 
ration, where reported. Pisonia has been reported anecdotally for medicinal use to treat cough, dysentery, fevers, rheumatic disease and venereal disease (Table 1).

For Salpianthus, anecdotal reports of medicinal use are attributed to Mexico (Table 1). Salpianthus has been reported anecdotally for medicinal use as an anti-diabetic and to treat diabetes (Table 1).

Moerman (1998) gave anecdotal reports of medicinal use of the Nyctaginaceae attributed to Native Americans in North America (Table 1). Nyctaginaceae have been reported anecdotally for medicinal use by Moerman as a "life medicine" for health in newborns, to both control and increase appetite, as an astringent, to treat bladder problem and boils, to apply to broken bones and bruises, as a cathartic, to treat coughs also for veterinary coughs, to treat dandruff and delirium, as a diuretic, to treat dizziness, to neutralize the effects of swallowing a spider, as an emetic, to treat fainting and fainting spells, as a febrifuge for eruptive fevers, to treat gonorrhea and headaches, to support the kidneys, to treat nausea, neuralgia and perspiring feet, as a post-partum treatment, for a poultice to treat burns, as a purgative, as sedatives for children, to treat snake bite, sore mouth, spider and insect bites, to apply to sprains, to treat stomach cramps and stomach disorders, as a sudorific, to treat swellings, swollen glands particularly in the throat, and as a vermifuge.

\section{Anecdotal Reports of Food and Fodder Uses of the Nyctaginaceae}

Food and forage uses of Nyctaginaceae genera - anecdotal reports (Table 2) includes information from Standley (1911), Smith (1932), Gunther (1945), Cárdenas (1969), Martínez (1969), Bogle (1974), Walker (1976), Chang et al. (1983), Popenoe et al. (1989), Sperling and King (1990), Cabieses (1995), Basualdo et al. (1995), NAPRALERT (1998), Ugent and Ochoa (2006), and Kritzer Van Zant (2016a), in addition to family level information from Moerman (1998).

Food use for Abronia has been reported for Native American tribes including the Makah and Kallam from western Washington State, and in the Pacific Coast region of the United States (Table 2). Only roots have been specified for food in reports for Abronia (Table 2). Pigs dug Allionia tubers for food (Table 2).

Food use for Boerhavia has been attributed to Peru, South America and Australia (Table 2). Boerhavia roots and leaves have been reported as food (Table 2). Boerhavia leaves have been used in soups (Table 2). Colignonia has been reported as food, attributed to Peru (Table 2).

Food use for Mirabilis has been attributed to Ecuador, Peru, Lake Titicaca for both Bolivia and Peru, the Andes, the southern Ryuku Islands, Japan, Okinawa, China and India (Table 2). Mirabilis roots, leaves, flowers and starch have been reported as food (Table 2). Mirabilis has been cultivated and cured to sweeten, and also cultivated as a sweet form. Mirabilis roots have been dried and eaten like carrots, leaves have been used in soups and salads, and the starch in Japan for specialty baking (Table 2). Mirabilis flowers have been used as a food dye in China (Bogle, 1974).

Popenoe et al. (1989) and Cabieses (1995) discuss use of cultivated M. expansa for food in the Andes, and in particular for Cabieses, in the region of Lake Titicaca for both Peru and Bolivia. Both authors discuss M. expansa's nutritional value, potential as a future crop, and note it has become rare in Peru and the Andes. Our experience in Ecuador is similar regarding $M$. expansa's scarcity. Cabieses says that fresh dug roots contain substances which irritate the mucosa of the mouth, but curing the plant in the sun transforms roots, giving them a sweet, attractive flavor. Popenoe et al. (1989) says Ecuadorian M. expansa is a sweet form, not astringent like $M$. expansa in Peru, and discusses the plant's use for forage. Our nutrition research supports claims of high protein values for roots and leaves (Kritzer Van Zant, 2016a). Sperling and King (1990) describe M. expansa as one of the roots and tubers of the Andean crop complex. The high density of raphides that we have seen in M. expansa, most likely made of calcium oxalate, may affect how mature leaves as well as roots of $M$. expansa and other Nyctaginaceae taxa should be processed for use as food, particularly for humans.

Food use for Pisonia has been reported, attributed to New Guinea and the Pacific and apparently Malaysia (Table 2). Pisonia leaves were used as a pot-herb in the Pacific and trees were cultivated, apparently for food, in Malaysia (Bogle 1974; Table 2 below). Pisonia has been used in New Guinea as a source for salt (NAPRALERT, 1998; Table 2 below).

Unspecified Nyctaginaceae genera were mentioned as used for food in Bolivia, Paraguay and Mexico, by Cárdenas (1969), Basualdo et al. (1995), and Martínez (1969), respectively (Table 2 ). This information was combined by us with information from Moerman (1998) for an overview of food use for the Nyctaginaceae at the family level (Table 2). Specific information was sometimes included for the Nyctaginaceae, by Moerman (1998) for roots, leaves, fruits and seeds, as well as the previous mention of starch for Mirabilis by Chang et al. (1983) (Table 2).

As for water in which $M$. expansa roots were boiled in the Andes, leaves of Nyctaginaceae were used by North American tribes for making refreshing cold drinks as well as for tea (Moerman, 1998; Table 2 below).

\section{Anecdotal Reports of Other Uses of the Nyctaginaceae}

Lumber, floriculture and other uses of Nyctaginaceae genera - anecdotal reports (Table 3) includes information from Ruiz (1777-1788 (1940)), Bogle (1974), Hamel and Chiltoskey (1975), Walker (1976), Olsson (1991), Basualdo et al. (1995), Armstrong (1998), NAPRALERT (1998), Burger (2005), and Agrebi et al. (2008), in addition to family level information from Moerman (1998). Boerhavia has been reported as used for flypaper (NAPRALERT (1998); Table 3 below). Pisonia has also been used for its sticky substances (see below).

Bougainvillea and Commicarpus have been cultivated in Okinawa and the southern Ryuku Islands, respectively (Table 3). This is apparently for landscaping and/or floriculture.

Mirabilis has been reported for several uses in addition to food and medicine, attributed to Japan, Okinawa, the southern Ryuku Islands and North America (Table 3).

Mirabilis starch has been used alone as a cell medium for extracellular protease production in Bacillus spp. (Table 3). M. 
Table 2. Food and Forage uses of Nyctaginaceae genera* -anecdotal reports.

\begin{tabular}{|c|c|c|c|c|c|c|}
\hline Use & Genus & Plant Part & Preparation & Tribe & Location & Source \\
\hline food & Boerhavia & roots & & & Australia & Bogle (1974) \\
\hline food & Boerhavia & roots & & & Peru & Bogle (1974) \\
\hline food & Colignonia & & & & Peru & Ugent and Ochoa (2006) \\
\hline food dye & Mirabilis & flowers & & & China & Bogle (1974) \\
\hline food & Mirabilis & & sometimes eaten & & Okinawa & Walker (1976) \\
\hline food & Mirabilis & & cultivated & & Andes & Popenoe et al. $(1989,1990)$ \\
\hline food & Mirabilis & & cultivated, cured to sweeten & & Peru, Lake Titicaca & Cabieses (1995) \\
\hline food & Mirabilis & & cultivated, cured to sweeten & & Bolivian, Lake Titicaca & Cabieses (1995) \\
\hline food & Mirabilis & & cultivated sweet form & & Ecuador & Popenoe et al. (1989) \\
\hline forage & Mirabilis & & & & Andes & Popenoe et al. (1989) \\
\hline food & Mirabilis & roots & crop & & Andes & Sperling and King (1990) \\
\hline food & Mirabilis & & & & Peru & Ugent and Ochoa (2006) \\
\hline food & Mirabilis & roots & & & India & NAPRALERT (1998) \\
\hline food & Nyctaginaceae & & & & Bolivia & Cárdenas (1969) \\
\hline food & Nyctaginaceae & & & & Paraguay & Basualdo et al. (1995) \\
\hline food? & Pisonia & leaves & cultivated tree & & Malaysia & Bogle (1974) \\
\hline food & Pisonia & leaves & pot-herb & & Pacific & Bogle (1974) \\
\hline salt & Pisonia & & & & New Guinea & Bogle (1974) \\
\hline food & Abronia & roots & sometimes eaten & Nat Am & & Standley (1911) \\
\hline food & Nyctaginaceae & leaves & $\begin{array}{l}\text { for making tea and } \\
\text { refreshing cold drinks }\end{array}$ & Nat Am & N Am & Moerman (1998) \\
\hline food & Nyctaginaceae & fruits & & Nat Am & N Am & Moerman (1998) \\
\hline food & Nyctaginaceae & seeds & & Nat Am & N Am & Moerman (1998) \\
\hline food & Mirabilis & starch & specialty baking & & Japan & Chang et al. (1983) \\
\hline
\end{tabular}

-Nat Am = unspecified Native American tribes; $\mathrm{N} \mathrm{Am}=$ North America.

-Moerman (1998) is only cited here at the family level. As for all of the authors most information given at the genus level is available at the spp. level in the original source. -Although some categories of use probably overlap, they were not compiled further as their exact meaning may have slightly different definitions in different sources.

-An attempt was made to set up the coding of use so that similar descriptions of use would sort in succession, though this was not always possible.

jalapa tuber starch, by itself, has been shown to provide all carbon, nitrogen and salts needed by Bacillus (Agrebi et al., 2008). Ground seeds of Mirabilis have been used as a cosmetic powder and unspecified parts for face powder (Table 3). Varied parts of Mirabilis have been used for dye (Table 3). Mirabilis nyctaginea (Michx.) MacMill. leaves were soaked in milk to make a fly poison (Hamel and Chiltoskey, 1975; Table 3 below). As Walker (1976) said for Bougainvillea, M. jalapa was commonly cultivated on Okinawa and the southern Ryukyu Islands, and though it is also not native there, it is frequently utilized in flower gardens, again particularly in the tropics (Table 3). Walker (1976) recounts that $M$. jalapa sometimes escapes, in one or both of these locations.

Neea fruits were used as a source of bright violet dye (Table 3). Neea leaves were chewed to blacken teeth to prevent tooth decay in Columbia and Peru (Table 3).

Pisonia also has uses besides medicine and food. Pisonia was used for lumber in Argentina and Jamaica (Table 3). Sticky substances are exuded from projections on the persistent calyx of Pisonia in the Pacific and Western Indian Ocean (Table 3). 


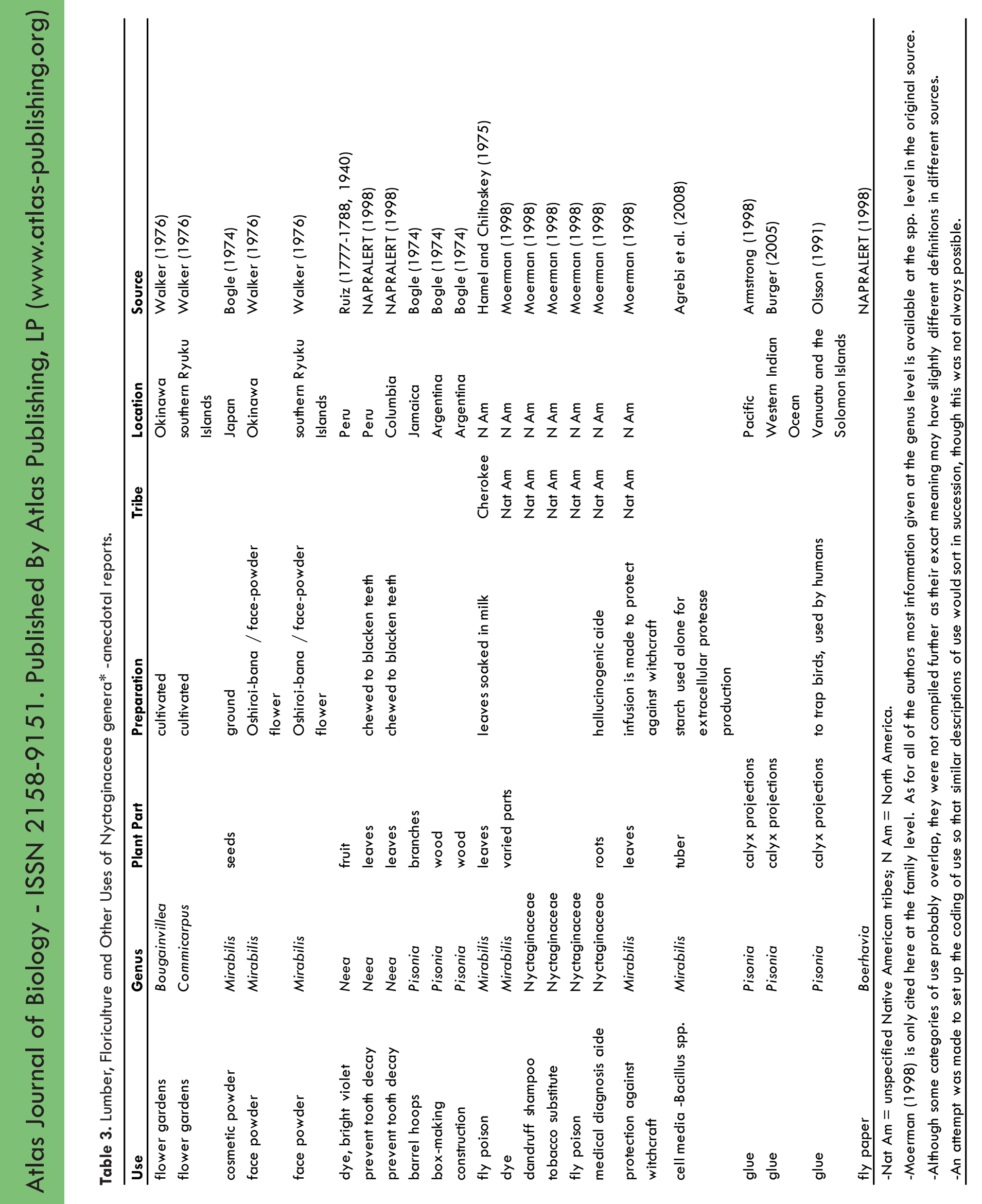


Table 4. Nyctaginaceae genera* -results of laboratory analyses.

\begin{tabular}{|c|c|c|c|c|c|c|}
\hline Genus & Plant Part & Preparation & compound & assay target & action & Source \\
\hline Mirabilis & seeds & isolated & peptides, two & bacteria, 2 gram positive & active against & Cammue et al. (1992) \\
\hline Mirabilis & seeds & isolated & peptides, two & bacteria, gram negative & inactive & Cammue et al. (1992) \\
\hline Mirabilis & seeds & isolated & peptides, two & cells, cultured human & inactive & Cammue et al. (1992) \\
\hline Mirabilis & seeds & isolated & peptides, two & fungi, 13 pathogenic & active against & Cammue et al. (1992) \\
\hline Mirabilis & seeds & isolated & peptides, two & insects, pulse-transmission & $\begin{array}{l}\text { inactive, similar to spider } \\
\text { neurotoxic peptides }\end{array}$ & Cammue et al. (1992) \\
\hline Boerhavia & & extracted & & cells, HIV infected & activity, weak & NAPRALERT (1998) \\
\hline Boerhavia & & extracted & & $\begin{array}{l}\text { Pseudomonas aeroguinosa } \\
\text { (Schroeter) Migula }\end{array}$ & active against & NAPRALERT (1998) \\
\hline Boerhavia & & extracted & & $\begin{array}{l}\text { Staphylococcus aureus } \\
\text { (Rosenbach) Zopf }\end{array}$ & active against & NAPRALERT (1998) \\
\hline Boldoa & & & & $\begin{array}{l}\text { Escherichia coli (Migula) } \\
\text { Castellani and Chalmers }\end{array}$ & active against & NAPRALERT (1998) \\
\hline Boldoa & & & & $\begin{array}{l}\text { Propionibacterium acnes } \\
\text { (Gilchrist) Douglas and } \\
\text { Gunter }\end{array}$ & active against & NAPRALERT (1998) \\
\hline Boldoa & & extracted & & $\begin{array}{l}\text { Pseudomonas aeroguinosa } \\
\text { (Schroeter) Migula }\end{array}$ & active against & NAPRALERT (1998) \\
\hline Boldoa & & & & $\begin{array}{l}\text { Salmonella typhosa (Zopf) } \\
\text { White }\end{array}$ & active against & NAPRALERT (1998) \\
\hline Boldoa & & & & Sarcina lutea Schroeter & active against & NAPRALERT (1998) \\
\hline Boldoa & & & & $\begin{array}{l}\text { Shigella flexneri (Flexner) } \\
\text { Castellani and Chalmers }\end{array}$ & active against & NAPRALERT (1998) \\
\hline Boldoa & & & & Staphylococcus aureus & active against & NAPRALERT (1998) \\
\hline Bougainvillea & & & & $\begin{array}{l}\text { Bacillus subtilis (Ehrenberg) } \\
\text { Cohn }\end{array}$ & active against & NAPRALERT (1998) \\
\hline Bougainvillea & & & & Staphylococcus aureus & active against & NAPRALERT (1998) \\
\hline
\end{tabular}

Used for dispersal of fruits, this natural glue from Pisonia was also used by humans to trap birds on Vanuatu and the Solomon Islands (Table 3). This glue has been reported to persist for many decades on Pisonia herbarium specimens, and can be diluted with water (Burger, 2005). Boerhavia's sticky surfaces have also been used for related purposes (Table 3).

Branches of Jamaican Pisonia are utilized for barrel hoops, and wood in Argentina is used for box-making and construction (Table 3).

Moerman (1998) also reported uses other than medicine and food for the Nyctaginaceae by Native Americans in North America (Table 3). Native Americans used the Nyctaginaceae for dandruff shampoo, fly poison and a tobacco substitute (Table 3). There were mystical uses as well. Nyctaginaceae roots were used as a hallucinogenic aide for medical diagnosis (Table 3). Leaves of Nyctaginaceae were used for making an infusion to protect against witchcraft (Table 3).

\section{Laboratory Analyses of Nyctaginaceae}

Nyctaginaceae genera - results of laboratory analyses (Table 4) consists of results reported for chemical isolations and extracts from Boerhavia, Boldoa, Bougainvillea, Cryptocarpus, and Mirabilis, utilized in assays. These assay results are summarized from published data in Cammue et al. (1992),
Pelayo-Benavides and Anaya (1993), Vivanco et al. (1997; 1999a, b), NAPRALERT (1998), Vivanco and Flores (2000), and Vepachedu et al. $(2003,2005)$ (Table 4). Information on our update of the nomenclature for the target organisms is given after the summary of activity for these genera. Chemical constituents of leaves of M. jalapa, apparently from India, were studied by Behari, et al. (1975), though no details were given by them for individual assays, so there was insufficient information to include their results in Table 4.

Boerhavia extracts are weakly active against HIV infected cells, and active against Pseudomonas aeroguinosa (Schroeter) Migula and Staphylococcus aureus (Rosenbach) Zopf (Table 4).

Boldoa is active against Escherichia coli (Migula) Castellani and Chalmers, Propionibacterium acnes (Gilchrist) Douglas and Gunter, Pseudomonas aeroguinosa (Schroeter) Migula, Salmonella typhosa (Zopf) White, Sarcina lutea Schroeter, Shigella flexneri (Flexner) Castellani and Chalmers, and Staphylococcus aureus (Table 4). Bougainvillea is active against Bacillus subtilis (Ehrenberg) Cohn, and Staphylococcus aureus (Table 4). Cryptocarpus is active against Neurospora crassa Shear and B. O. Dodge (Table 4).

Mirabilis material has activity against Enterobacter Hormaeche and Edwards spps., Epidermophyton floccosum (Harz) Langeron and Miloch., Escherichia coli (Migula) Castellani and Chalmers, Salmonella typhosa, Shigella flexneri, Staphylococcus 


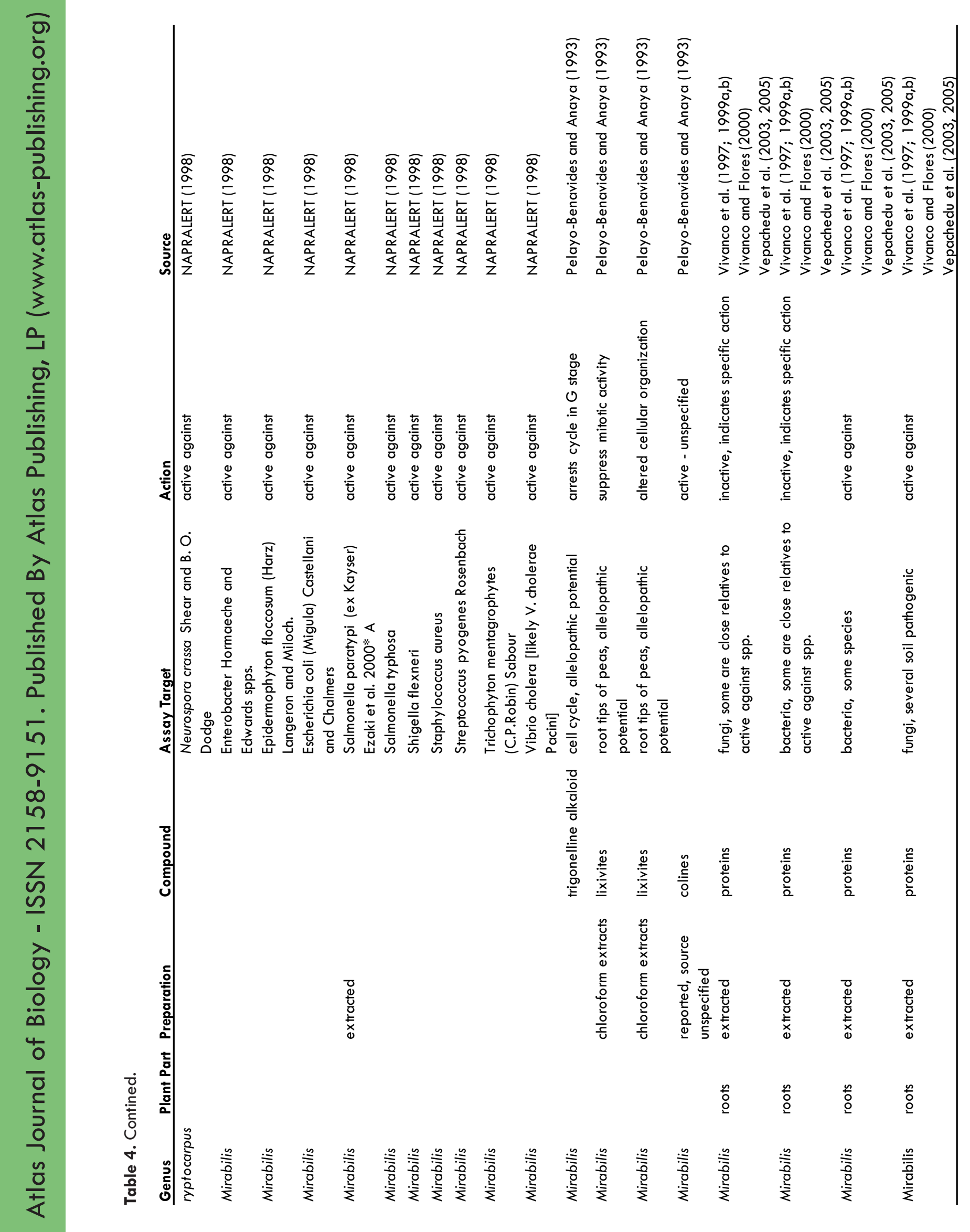


aureus, Streptococcus pyogenes Rosenbach, Trichophyton mentagrophytes (C. P. Robin) Sabour and Vibrio cholera [likely V. cholerae Pacini] (Table 4). An extract of Mirabilis was active against Salmonella paratypi (ex Kayser) Ezaki et al. 2000* A (Table 4).

Two peptides of M. jalapa, isolated from seeds, are selectively active for two gram positive bacteria and inactive against cultured human cells of unnamed origin (Table 4). Extracted root proteins from Mirabilis are selectively active against bacteria (Table 4). A trigonelline alkaloid from $M$. jalapa arrests the cell cycle in the G2 stage (Table 4). The same two peptides found active against two gram positive bacteria, are active against 13 pathogenic soil fungi (Table 4). These same two peptides isolated from $M$. jalapa seeds were found to have chemistry similar to spider neurotoxins, yet were inactive for pulse transmission in unspecified insects (Table 4). Extracted Mirabilis root proteins are selectively active against several soil pathogenic fungi, and this selectivity is sometimes for closely related fungal species (Table 4).

Lixivites from chloroform extracts of Mirabilis both suppressed mitotic activity and altered cellular organization, in the root tips of peas (Table 4). Colines from M. oxybaphus were reported as having unspecified activity (Table 4).

\section{Taxonomic Updates of Microorganism Names}

Author names were not given in NAPRALERT (1998) for microorganisms utilized in assays. These names were updated here as well as we could, based on NCBI (2011) and its considerable links, EBICBN (1958), and taxonomic literature for individual taxa. Several points are added here about those taxonomic updates. Once again, an asterisk indicates that we did not see the original source of information. Salmonella paratypi is a rejected name for S. enterica Kauffmann and Edwards subsp. enterica (ex Kauffmann and Edwards) Le Minor and Popoff 1987* serovar Paratyphi A, though S. enterica (ex Kauffmann and Edwards) Le Minor and Popoff $1987^{*}$ is apparently an earlier rejection of S. enterica which has since been overturned, as this rejected version of the name is listed as a synonym of S. enterica (NCBI, 2011). It is also unclear if subsp. enterica is the currently accepted name for the subspecies or if subsp. is the new correct name, or who authored this last name or the names serovar or Paratyphi in conjunction with the genus name Salmonella (NCBI, 2011 ). These are questions for the original authors of the assay research and/or taxonomists specializing in those organisms. We also specified Enterobacter Hormaeche and Edwards spps. Enerobacter Rahn which is also in the literature, though it does not appear to be a legitimate name.

NAPRALERT (1998) had many more reports of inactivity than of activity for the Nyctaginaceae, often indicating specific mechanisms when activity was found.

\section{Reports of Toxicity for Mirabilis}

The single report in NAPRALERT, of human toxicity from consumption of M. jalapa, is from Singapore, and was derived from an incomplete abstract that we have so far been unable to trace to the original source. It is also unclear if this toxicity is as be- nign as a mild stomach ache or refers to a poisoning resulting in death. It may refer to consumption of an improperly processed root, or toxicity due to some mitigating factor such as contaminated soils. The reports of using Nyctaginaceae and M. nyctaginea in particular to make fly poison, may simply be a matter of concentrated oxalic acid crystals dissolving into liquid, or alternatively, the presence of a Class I ribosome inhibitor protein which only affects insects. Either way, these reports point to the need for proper preparation or utilization of Mirabilis and other Nyctaginaceae species for food, which may or may not only be safe to eat in certain stages of development or for certain parts of the plant, or both. There is a need for further investigation of toxicity before any Mirabilis spp. should be adopted as a modern food on a wide scale. Our own negative toxicity data for $M$. expansa extracts are highly preliminary, and insufficient to fully address this question. This data is from a small scale study on young plants grown in constructed plots in a single local, and only concerns micro-molecules and not peptides or proteins. However, our results do not indicate that there is a toxic micromolecule in $M$. expansa, which is encouraging for $M$. expansa's future as a food source, even if some form of processing is required to remove or mitigate the oxalic acid.

Many plants utilized extensively for food have toxic parts, including carrots, potatoes and cashews. These crops have been proven to be a boon for agriculture, human and animal nutrition, and culinary purposes, once methods were established for their safe preparation. In addition, varieties of food plants with toxins or irritants have proven valuable for their insect and pest resistance as exemplified by the sweet versus bitter varieties of Manihot esculenta Crantz (Euphorbiaceae) 1766 (IPNI, 2011), also known as tapioca, manioc, bitter cassava, or yuca. Again, it is a matter of knowledge of techniques for proper preparation. Therefore, it may be that M. expansa and perhaps other Nyctaginaceae species will prove useful as cash crops, with proper processing prior to consumption of more than small amounts for food.

\section{Archeological Significance of small starch particles in Mirabilis}

M. jalapa starch has been used for specialty baking in Japan, because of the extremely small size of the starch particles (Chang et al., 1983). Minute starch particles in M. jalapa were seen by ourselves under magnification of about $30,000 \mathrm{x}$, under both scanning and transmission electronic microscopes. Both techniques require fixed material for imaging (Bozzola and Russell, 1999). We were unable to see $M$. jalapa starch grains under a standard microscope at 1000X. This lower magnification is used for archeological studies in which plants are identified using starch techniques. These techniques use starch which has not been fixed (Ugent et al., 1986; Ugent and Peterson, 1988; Ugent and Cummings, 2004; Torrence and Barton, 2006). This may be why $M$. expansa is not reported from examination of excavated tools for preparing foods, found at archeological sites in the Andes. It may also be why there have not been archaeological reports of $M$. jalapa starch for food in Mexico. Top soil over sand over gravel is characteristic of the plaza at the Incan site of Machu Picchu in Peru (Nova, 2010). The garden terraces 
leading up to Machu Picchu were of the same construction as the plaza (Tpompo, 2012). Sand over gravel is also characteristic of the plots used to successfully grow $M$. expansa outdoors in southern Illinois (Kritzer Van Zant, 2016a). It is plausible that M. expansa played a role in allowing the Incas to occupy their highest altitude cities, even though this is not known from previous archeological research in the Andes.

\section{Update of Taxonomic Nomenclature Relating to Medicinal Jalap}

Mirabilis jalapa L. is the type for the family, and also the first Nyctaginaceae species for which we have found published reported use by humans. To understand how medicinal jalap and $M$. expansa are intertwined it is helpful to understand the plant's modern history, including its taxonomy. Nyctaginaceae is a conserved name based on the genus name Nyctago Juss., which is a synonym of Mirabilis L., according to Article 19 of the 1966* ICBN (International Code of Botanical Names) (Douglas and Spellenberg, 2010). M. jalapa appears to have been distributed horticulturally in the British Empire from the first quarter of the 16th century, which includes nearly the earliest years of the Spanish conquest of Mexico. Clusius (1583) named a specimen from India Admirabili Peruana, which based on the description and included drawing, is clearly a synonym for M. jalapa L. Peruana is either a species epithet, or Clusius attributed Mirabilis' origin as a genus to Peru, according to Mirabilis literature and type descriptions of Admirabilis, Bryonia, Jalap, Jalapa, and Jalappa. Admirabili or Admirabilis, is the earliest Pre-Linnaean Latin synonym of Mirabilis found in the course of taxonomic work on Mirabilis by this author. Bogle (1974) dates European horticultural use of $M$. jalapa to an even earlier date, 1552. Bogle based this on a drawing in the Badianus Manuscript attributed to Emmart [undated*]. Bogle goes on to say that according to Curtis (1797*) and Showalter (1934), European introduction of M. jalapa by the Spaniards occurred earlier still, in 1552.

Mirabilis jalapa L. was apparently given its specific name because of its presence in Xalapa, Mexico. The specific name jalapa was also used by Linnaeus for a plant of similar appearance in the Convolvulaceae (see below). This plant, like Mirabilis, has a complex taxonomic history, and was the real source of medicinal jalap (Felter and Lloyd, 1898 (2010)). M. jalapa has been used as a substitute source of medicinal jalap. However, it was unclear to us if this substitution was real, or reported due to confusion over the names. Walker (1976), while writing about the Nyctaginaceae in Okinawa and the southern Ryuku Islands, states that jalap resin has been extracted from M. jalapa roots, apparently in reference to historical extraction of jalap in Mexico or Spain. It was not clear from Walker if M. expansa had ever been used for this purpose in the Pacific as well. $M$. expansa's identification as medicinal jalap was an "erroneous belief" according to Bogle (1974).

Convolvulaceae is the family in which true medicinal jalap and several sometimes substituted relatives belong taxonomically. These relatives of true jalap are medicinally of inferior quality. Several of these relatives have vernacular or common names including the term 'jalap'. Felter and Lloyd (1898 (2010)) seem to be the source of much of the information and error found on a website for medicinal Jalap (Annonymous, 2010). Annonymous (2010) also includes information on medicinal use of Jalap from Grieve (1931). This website steered us to Felter and Lloyd for detailed information on the use of $M$. jalapa as a substitute source for jalap syrup. Prior to reading Felter and Lloyd, this author had only seen vague notes on $M$. jalapa as a substitute source of Jalap, with little detail included. Presented next is the story of Jalap with updated notes on the taxonomy.

Bryonia mechoacana nigricans [no author given (Felter and Lloyd, 1898 (2010), Annonymous 2010), was the first name applied to the true medicinal jalap plant. This Latin name first appeared in 1609 (Felter and Lloyd, 1898 (2010)), Annonymous 2010 ) and would actually be $B$. mechoacana nigrícans $C$. Bauhin (1620). Linnaeus (1753) used the spelling 'nigracans'. The author name 'Bauh,' which belongs to two different Bauhins and was given with three citations by Linnaeus (1753). Linnaeus first citation is 'Bauh. pin. 293', which was 'Pinax Theatri Botanici 1671' by Caspar (Gaspard) Bauhin (1560-1624). This author today is abbreviated as C. Bauhin. The second citation is 'prod. 135', which was most likely 'Prodromos Theatri Botanici.' This title was abbreviated in IPNI (2010) as 'Prodr. (Bauhin) edition 1 1620,' also by C. Bauhin. The earliest of Linnaeus' three 1753 citations; 'Bauh, hist. 2. P. 151 ' is J.Bauhin et al.'s 'Historia plantarum universalis nova, et absolutissima: cum consensu et dissensu circa eas. ...,' published from 1650-1651* (IPNI, 2010). J.Bauhin is Jean Johannes Bauhin (1541-1613) (IPNI, 2010).

Next, Ray named medicinal jalap Convolvulus americanus [undated]* (Felter and Lloyd, 1898 (2010)), Annonymous 2010). Linnaeus' author name for C. americanus appears as if it is spelled 'Raj.' However, there is no author abbreviation spelled 'Raj.' (IPNI, 2010, Brummitt and Powell, 1992). Ray is named author of C. americanus in both Felter \& Lloyd (1898 (2010)) and Annonymous (2010). This is John Ray (1627-1705) (IPNI, 2010). John Ray (1682) includes Latin descriptions of Convolvulus and C. nigra, with the species name given on page 68 , not page 67 as Ray referenced in his index. We have not found a description nor mention of C. americanus by Ray. IPNI (2010) gives C. americanus (Sims) J.W.Louden 1844*, C. americanus Greene 1898*, and C. americanus (Sims) Greene, for a variety of C. americanus named by Sims in 1804*. However, C. americanus Ray is not in IPNI. As C. americanus Ray is pre-Linnaen, it cannot have been validly published by Ray. Linnaeus (1737) added after 'Convolvulus americanus' the words "Jalapium dictus" meaning 'called Jalapium'. No doubt Linnaeus meant Jalapium is the common name. But Linnaeus (1737) also includes 'Jalapium \& Mechoacana nigra S.Dale [1693*-1737*]' as synonyms of Mirabilis. Felter and Lloyd (1898 (2010)) and Annonymous (2010) erred, in utilizing 'Convolvulus americanus Jalapium dictus' in full as Ray's name for medicinal jalap, slightly misinterpreting Linnaeus (1737) and possibly Ray as well.

Tournefort identified medicinal jalap as Mirabilis, after being "deceived" by persons who claimed to know the plant (Felter and Lloyd, 1898 (2010); Annonymous 2010). Perhaps this was an honest mistake by Tournefort's sources as both plants have enlarged roots and large tubular flowers. Also, frequently specimens of $M$. jalapa and many Convolvulaceae taxa have cordate leaves. In addition, both M. jalapa and medicinal jalap 
have been reported as purgatives. Whether due to deliberate deception or innocent misidentification by others, Tournefort's misidentification led to further confusion about the identity of medicinal jalap and more names. Balfour identified medicinal jalap as Exogonium purga, though no author was given (Felter and Lloyd, 1898 (2010)) and Annonymous (2010). E. purga Lindl. (Convolvulaceae) 1847 is given as a legitimate name in IPNI (2010).

Linnaeus named true jalap Convolvulus jalapa (Felter and Lloyd, 1898 (2010); Annonymous 2010), which IPNI (2010) dates as 1767. Linnaeus had named the type specimen for M. jalapa in 1753 so he at least was not confused about the taxonomic identities of these two plants. Differences of opinion continued until 1827, when J.R. Coxe of Philadelphia, obtained perfect flowers from roots of true jalap plants taken directly from their native Mexican soils (Felter and Lloyd, 1898 (2010); Annonymous 2010). Felter and Lloyd (1898 (2010)) and Annonymous (2010), state that Coxe's new material was named Ipomoea purga Wender. \& Hayne. However, the earlier I. jalapa Nutt. (Convolvulaceae) at first appears more likely to be the correct legitimate name for medicinal Jalap. IPNI (2010) attributes I. purga $1833^{*}$ separately to each author in the same publication in, "Arzneyk. Ann. 12: pls 33, 34". However, IPNI (2010) does not attribute this name to both authors together. Perhaps one was the editor. In addition IPNI (2010) has I. jalapa Scheiede \& Deppe ex G.Don, and I. jalapa Pursh 1813*. However, the title page in both volumes of Pursh is dated 1814. It may be that 1813 is the year of acceptance for the document and 1814 the year of publication. IPNI (2010) also attributes to the same source I. jalapa (L.) Pursh, with the date 1814*, and I. jalapa Coxe 1829 (1830)* cited from "Journ. Am. Med. Sc. v....300." However, I. jalapa Nutt. is not currently found in IPNI.

Common names for medicinal jalap (Convolvulaceae), relevant for understanding M. jalapa references, include in Englishjalap, fusiform jalap, jalap bindweed, Tampico jalap, true jalap, in German- Jalap, Swedish- jalap, jalapa, jalaparot, Portugese- jalapa, Spanish- jalapa, and mechoacán (Felter and Lloyd, 1898 (2010)). Four other plants in the Convolvulaceae include jalap in their common names and are used as substitute sources of medicinal jalap, though they are of lower quality than true Jalap. First is I. Orizabensis (Pellet.) Ledeb. ex Steud., with English common names fusiform jalap, jalap stalks, jalap tops, light jalap, male jalap, Orizaba jalap, and woody jalap. Second is $I$. pandurata (L.) G.Mey, synonym C. panduratus L., with the English common name wild jalap. Third is I. simulans Hanb. with the English common name Tampico jalap. Fourth is Operculina turpethum (L.) R.Br., syn I. turpethum (L.) R.Br., with the English common name Indian jalap (Felter and Lloyd, 1898 (2010)). Thus, the potential exists to find entanglements in the literature for M. jalapa with all of these species, as well as with true jalap.

Though we have laid out the story and partially clarified the references for medicinal jalap in the Convolvulaceae, we did not confirm references marked with asterisks or evaluate many of the original sources beyond their presentation in IPNI. The final decision as to the proper name of true medicinal jalap is left to those who study the Convolvulaceae. What matters in this story for Mirabilis taxonomy, is that the origin of several mysterious synonyms, including both genus names and species epithets, and of common names mixed into synonym lists or utilized as Latin synonyms by some authors for M. jalapa in the literature, can now be understood in terms of their place in the Convolvulaceae. Examples are Linnaeus' (1737) inclusion of the genus names Bryonia, Jalapa, Jalapium, Mechoacana, and Convolvulus as synonyms for Mirabilis. As for economic application, reports of M. jalapa as a low quality substitute for medicinal jalap, could either be real, based on the uses reported above from many sources for this plant, or could be a simple case of mistaken identity based on inaccurate identification and confused taxonomy.

M. jalapa contains calcium oxalate raphide crystals, true jalap does not (Felter and Lloyd 1898 (2010); Annonymous 2010). It is these large calcium oxalate raphides, reported for Mirabilis and at least some other Nyctaginaceae, which may be responsible for some of the soothing and purgative effects of Mirabilis reported in traditional medicine. Still, the effects of proteins and peptides have been shown to go well beyond this, and there is potential for new anti-fungal and anti-bacterial compounds for both agriculture and medicine in the family. Yet few people today are familiar with the uses of these plants. Lawrence (1951, 1970) predates Bogle (1974) in saying that the Nyctaginaceae are economically of little domestic importance. This may be due to two linked issues, confusion over taxonomy, and insufficient research on useful taxa in the family.

\section{Historical Precedence for Mirabilis spp. as Experimental Organisms in Plant Breeding and Genetics}

There is a long history of plant breeding with Mirabilis. At the time of conquest, Europeans found indigenous peoples breeding M. jalapa for its flowers in Mexico, and M. expansa for food in the Andes. Western science also has a long record of experimentation with breeding Mirabilis. These experiments were among those that helped with the formulation of some basic theoretical concepts in plant genetics, and therefore have yielded information which became of economic value.

In Linnaeus' dissertation, he recorded as his first experiment, emasculating flowers of $M$. longiflora $L$., then pollinating them with pollen from M. jalapa (Roberts, 1929). Linnaeus noted that ovules grew from this cross, though they did not mature (Roberts, 1929). Later, Linnaeus pollinated M. longiflora flowers with pollen from other flowers of the same species, and observed that seeds matured. Linnaeus then experimented further with pollen utilizing other taxa, leading him to conclude that such experiments demonstrate, "the generation of plants" (Roberts, 1929).

Nineteenth century German doctor and plant breeder Wilhelm Olbers Focke noted that hybrid formation does not always succeed equally well in both directions (Roberts, 1929). Focke included Linnaeus' crosses of M. jalapa and M. longiflora as an example of greater or lesser seed production depending on the direction of pollination (Roberts, 1929). Darwin echoed this concept in the Origin of Species, also referencing Kolreuter's crosses with M. jalapa in the late 1700's (Roberts, 1929).

German botanist Kolreuter counted pollen grains used for crosses with M. jalapa, relating their numbers to numbers of seeds produced (Roberts, 1929). Kolreuter also crossed red-flowered 
with yellow-flowered M. jalapa and made the reciprocal cross, noting that an intermediate yellow-orange color resulted from both (Roberts, 1929). Kolreuter then back-crossed a yellowflowered individual to the hybrid, noting that the resulting flower color had a greater degree of yellow (Roberts, 1929). These crossing experiments by Kolreuter foreshadowed Mendel's work with garden peas. Professor Carl Correns, who rediscovered Mendel's paper on the latter's initial work with peas, and who also made his own crossing experiments with peas at the end of the 19th century, noted that Mirabilis jalapa was, "one of my most fruitful objects of research" (Roberts, 1929). Mendel (1865) praised Kolreuter and Lecoq among others, in the introduction to Experiments in Plant-Hybridisation.

French botanist Henri Lecoq was said by his 19th century contemporary, Dominique Alexandre Godron, to have observed that fertile hybrids of Mirabilis grown with their parents were more likely to produce offspring which returned to the parent type (Roberts, 1929). Godron, also French and a physician botanist, made a general rule about hybrids returning to the parental forms, based in part on Lecoq's work with Mirabilis (Roberts, 1929). However, Godron did not understand the true mechanisms involved (Roberts, 1929).

This author believes that Mirabilis and other Nyctaginaceae still have much to reveal about basic genetic principles. Our own observations on the apparently independent development of structures in Andean Mirabilis indicate to us that one of the greatest social and economic values for these plants may be in their usefulness for identifying epigenetic and ploidy patterns which impact evolution, particularly timing of expression.

$\mathrm{POH}$ gene's varied effect on embryo development, via timing of activation of the gene, is now thought to be responsible for arthropod limb variation seen in the pre-Cambrian fossil record (Carroll, 2005). POH is one of many such genes and sometimes single alleles, known to have dramatically different effects based on the frequency and duration of their activity in early embryonic development in animals (Carroll, 2005). Research to identify similar genes in plants has been underway (Grant-Downton and Dickinson, 2005; Schaacke et al., 2010). Phylogeny is being studied for the Nyctaginaceae and several genera within the family (Douglas and Spellenberg, 2010; Hernández-Ledesma et al., 2010; Hernández-Ledesma et al., 2015). However, there does not seem to be any recent or current studies of epigenetic and/or ploidy mechanisms which are likely to underlie the visually obvious, real time variation of expression frequently found in individuals in the Nyctaginaceae.

\section{Discussion}

Selective activity is important for drug discovery, which frequently begins with investigation of general cell toxicity. Selective activity indicates that extracts and isolates are less likely to harm healthy cells, at least at the right dosages. Selective activity is also important for agricultural application of molecules derived from biological materials, to crops intended for consumption by humans or livestock. As NAPRALERT (1998) reported more inactivity than activity in assays utilizing extracts and isolations from the Nyctaginaceae, specificity may be very high for many Nyctaginaceae active compounds.

Correct identification of any plant or other organism, is basic and necessary for meaningful extrapolation of research, from individuals or sample populations, to other members of the same taxon. Therefore correct identification is a basic ingredient in getting biological research funded. Confusing taxonomy has long been a problem for funding some types of research for many taxa in the Nyctaginaceae. In addition, epigenetic and ecological effects may powerfully affect chemical production for these taxa. Plants in many families show variation in production of bio-chemicals due to ecology, and probably also due to epigenetic factors. The wide range of ethnobotany reports, which include many unique descriptions of use, combined with high amounts of morphological plasticity, leads us to wonder if frequent profound biochemical plasticity occurs in the Nyctaginaceae. Morphological plasticity is frequently visible during development, for multiple structures on individual specimens in the family. As for any medicinal plants, it will be necessary to know if where and how plants are cultivated, impacts production of significant bio-chemicals, and if variation in production under different growth regiments, allows production to occur in a consistent manner. This understanding is necessary to set up successful commercial production for any organism, and has so far been little examined for the Nyctaginaceae.

Food and forestry uses will also require ecological and agricultural studies. This includes a better understanding of each species' potential to become invasive. This is an additional economic consideration for production of any species for use as crops, pesticides, dyes, adhesives, as well as for medical application.

M. expansa is not listed by the USDA as invasive. M. jalapa is a well-known invasive in the tropics. Though it does not winter over in temperate climates, $M$. jalapa is capable of re-seeding as an annual under some conditions under cultivation. North American M. nyctaginea (Michx.) Macmill., is both native (Mohlenbrock and Voigt, 1959, 1974; Spellenberg, 2006), and occasionally an invasive weed in the Midwest (Buckholtz et al., 1981, 1992). M. nyctaginea has also been reported as an "obnoxious weed" for some states (Spellenberg, 2006). M. macfarlanei Constance and Rollins, is a rare endemic in Idaho and Oregon, and possibly limited by availability of pollinators in its range, especially the low incidence of hawkmoths (Barnes, 1996, 1997).

Our observations of both M. jalapa and M. expansa, grown outside in southern Illinois, showed that both species are visited by multiple potential pollinators. These include hawkmoths, spiders, and ants. We witnessed herbivory on $M$. expansa by wooly caterpillars and by caterpillars of hummingbird moths. Thus, we believe it would be unwise to make assumptions about the behavior of Nyctaginaceae species grown under new conditions from their behavior under different conditions, without testing. Our work in southern Illinois with M. expansa indicates it is highly limited there by drainage and has little resistance to freezing weather including early frosts. However, M. expansa is a perennial crop in the Andean highlands (Flores et al., 2003), where freezing temperatures are common at night. This could be due to the age of the plants, and whether they have both been propagated and allowed to mature in a particular climate 
prior to strong seasonal changes. It may also be a function of better soil drainage and/or better snow cover in the Andes.

There are some questions to answer concerning food safety. There is a well-documented history of use as food for several members of this family. There is also indication of high nutritional value available for some Nyctaginaceae species for direct human consumption. In addition, Nyctaginaceae starch has been used as a medium for growing microorganisms for the production of valuable biochemicals. There is also potential to use some of these plants as sources of forage. Toxicity to mammals is not seen in the Nyctaginaceae literature, other than the single poorly substantiated report in humans, from M. jalapa, described above. Toxicity from the Nyctaginaceae has not been reported otherwise, even in taxa where high levels of biochemical activity have been reported.

Colleagues have told us that sustainable use of woody Nyctaginaceae genera such as Pisonia and Neea would benefit from improved taxonomic work. Lawrence $(1951,1970)$ includes Abronia with Mirabilis and Bougainvillea as notable garden ornamentals, adding even more economic value to the family. Highly plastic development, often seen in individual specimens of the Nyctaginaceae, may offer a great deal of insight into flowering plant evolution including ploidy and epigenetics.

\section{Conclusion}

Clearly the Nyctaginaceae has much to offer including sources of useful compounds and valuable agricultural material. These benefits should increase once their morphological taxonomy has been clarified. Mirabilis' and possibly other Nyctaginaceae genera's importance as paleo-foods requires further investigation, as the extremely minute size of starch grains in these plants would have prevented their recovery with current starch techniques, from tools for food preparation found at archaeological sites.

Nyctaginaceae genera, so far Abronia, Boerhavia and Mirabilis in particular, have already been shown to have medicinal value through world-wide examples of traditional use from multiple cultures. The production of potentially useful biochemicals by particular Nyctaginaceae species has been confirmed through published results of laboratory assays on specific compounds and their biochemical effects.

Certainly this family is a good candidate for fully funded studies of not only which genes are in which Nyctaginaceae taxa, but also of morphological taxonomy and systematics, epigenetic and ploidy mechanisms, medicinal bio-chemistry, archeo-botany, and further agricultural research including forestry of woody species, floriculture of both woody and herbaceous taxa, plant breeding, use of substrate material for industrial biochemical production, as well as more information on food and forage nutrition, chemistry and safety.

\section{Acknowledgements}

Thank you to J.M. Vivanco for his time. Thank you also to Bill Banz, Hee-Byung Chai, Douglas Kinghorn and David A. Lightfoot for their advice and assistance, and for their help in producing some of the data summarized in this paper from this author's dissertation. Carlos Ochoa and especially Donald Ugent encouraged that work and offered many insights into ethnobotany, taxonomy and the importance of Andean root crops, especially M. expansa. Our reviewers comments were of great use in improving the organization of this paper.

\section{References}

Agrebi R, N Hmidet, M Haijii, N Ktari, A Haddar, N Fakhfakh-Zouari and M Nasri (2008) Fibrinolytic Serine Protease Isolation from Bacillus amyloliquefaciens An6 Grown on Mirabilis jalapa Tuber Powders. Appl Biochem Biotech 162 (1): 75-88. Abstract downloaded 25 Jul 2011 from: http://www.springerlink.com/content/ p84q7351056j1wv7.

Annonymous (2010) Ancient Aztec Herbal Remedies; Jalapa - Jalap (I. jalapa). A Report Summarized from King's Amer Dispensatory by H.W.Felter and J.U. Lloyd. Downloaded 19 Sep 2010 from: http:// electrocomm.tripod.com/jalapa-jalap.html.

Armstrong WP (1998) Ultimate and painful hitchhikers; The deadly Pisonia tree of tropical Pacific islands. In: WP Armstrong (ed), Wayne's word; An on-line textbook of natural history. Downloaded 9 Aug 2010 from: http://waynesword.palomar.edu/plmay98. htm\#painful.

Barnes JL (1996) Reproductive ecology, population genetics, and clonal distribution of the narrow endemic; Mirabilis macfarlanei (Nyctaginaceae), Master's thesis, Utah State University-Logan, Utah.

Barnes JL (1997) Genetic Diversity, Gene Flow and Clonal Structure of the Salmon River Populations of Macfarlane's Four o'clock Mirabilis macfarlanei (Nyctaginaceae). Idaho Bureau of Land Manage 97(17): 1-62.

Basualdo I, EM Zardini, and M Ortiz (1995) Medicinal Plants of Paraguay: Underground Organs, II. Econ Bot 49(4): 393.

Bogle A.L. (1974) The Genera of the Nyctaginaceae in the Southeastern United States. J. Arnold Arb 55(1): 1-37.

Bozzola, JJ, and LD Russell (1999, 1992). Electron microscopy 2nd Edition. Jones and Bartlett, Toronto, ON, $694 \mathrm{Pp}$.

Brummitt RK, and CE Powell (1992) Authors of plant names. Royal Botanic Gardens, Kew, 740 Pp.

Buckholtz KP (ed) $(1981,1992)$ Weeds of the north central states; Bulletin 772. University of Illinois at Urbana-Champaign College of Agriculture Agricultural Experiment Station, p. 68.

Burger AE (2005) Seabirds Killed by Trees: Accident or Design, J. Trop Ecol 21: 263-271, partially reproduced, downloaded 9 Aug 2010 from: http://www.natureseychelles.org/index.php?option=content\& task=view\&id $=73$.

Cabieses F (1995) Cien siglos de pan; 10,000 años de alimentación en el Perú. CONCYTEC (Consejo Nacional de Ciencia y Tecnologia), Lima, pp. 71-72.

Cammue BP, MF De Bolle, FR Terras, P Proost, J. Van Damme, SB Rees, J Vanderleyden, and WF Broekaert (1992) Isolation and Characterization of a Novel Class of Plant Antimicrobial Peptides from Mirabilis jalapa L. Seeds, J. Biol Chem 267(4): 2228-33.

Carroll SB (2005) Endless forms most beautiful: The new science of evo devo and the making of the animal kingdom. Norton, New York, $550 \mathrm{Pp}$.

Cárdenas M (1969) Manual de plantas economicas de Bolivia. Icthus, Cochabamba, Bolivia, p. 35.

Chang SM, SL Tzeng, and CY Lii (1983) Isolation and Characterization of the Starch from Four-o'clock Flower Mirabilis jalapa Seed. J. Food Sci 48: 1238-41. 
Clusii [Clusius] C (1583) Atrebatis rariorum aliquot stirpium, per pannoniam, Austriam, \& vicinas quasdam provincias observatarum historia, quatuor libris expressa... Christopher Plantini, Antverpiae, pp. 395- 400. Downloaded 5 Dec 2010 from: http://www.biodiversitylibrary.org/item/15321.

Douglas N, and R Spellenberg (2010) A New Tribal Classification of Nyctaginaceae. Taxon 59(3): 905-910.

EBICBN (Editorial Board of the International Committee on Bacteriological Nomenclature) (eds.) (1958) International code of nomenclature of bacteria and viruses; bacteriological code. Downloaded 25 Jul 2011 from: http://www.biodiversitylibrary.org/ item/30286\#page/209/mode/1 up.

Felter HW, and JU Lloyd (1898 (2010)) King's Amer dispensatory. Downloaded 20 Oct 2010 from: http://www.henriettesherbal.com/ eclectic/kings/ipomoea-jala.html.

Flores HE, TS Walker, RL Guimarães, HP Bais, and JM Vivanco (2003) Andean Root and Tuber Crops: Underground Rainbows. HortScience 38(2): 161-167. Downloaded 7 Jan 2011 from: http://lamar.colostate.edu/ jivivanco/papers/Hort Science/2003.pdf.

Gilmore, MR $(1914,1919,1977)$ Uses of plants by the Indians of the Missouri River region. University of Nebraska Press, Lincoln, NE and London, G.B., p.26.

Gleason, HA, and A Cronquist $(1991,1993)$ Manual of vascular plants of northeastern United States and adjacent Canada; Second edition. The New York Botanical Garden, Bronx, NY, Ixxv, 910 Pp.

Grant-Downton, RT, and HG Dickinson (2005) Epigentics and its implications for plant biology. Invited review, 1. The Epigenetic network in plants. Ann Bot 96 (7): $1143-1164$.

Grieve, M (1931 (2010)) A modern herbal; vol. I, page on Bindweed, Jalap. Downloaded 20 Oct 2010 from: http://www.botanical.com/ botanical/mgmh/b/binwej40.html.

Gunther, E (1945, 1973, 1981) Ethnobotany of western Washington; The knowledge and use of indigenous plants by Native Americans. University of Washington Press, Seattle and London, p. 29.

Hamel, PB, and MU Chiltoskey (1975) Cherokee plants: Their uses - a 400 year history. Herald Publishing Company, Sylva, N.C., pp. 3435.

Hernández-Ledezma, P, HF Olvera, and H Ochoterena (2010) Cladistic Analysis and Taxonomic Synopsis of Anulocaulis (Nyctaginaceae) Based on Morphological Data. Syst Bot 35(4): 858-876. Downloaded 4 Feb 2016 from: http://www.bioone.org/doi/ full/10.1600/036364410X539916.

Hernández-Ledezma, P., WG Berendsohn, T Borsch, S Von Mering, H Akhani, S Arias, I Castañeda-Noa, U Eggli, R Eriksson, H FloresOlvera, S Fuentes-Bazán, G Kadereit, C Klak, N Kortkova, R Nyffeler, G Ocampo, H Ochoterena, B Oxelman, RK Rabeler, A Sanchez, BO Schlumpberger, and P Uotila (2015) A Taxonomic Backbone for the Global Synthesis of Species Diversity in the Angiosperm Order Caryophyllales. Willdenowia 45(3): 281-383. Downloaded 4 Feb 2016 from: https://www.researchgate.net/ publication/281712177_A_taxonomic_backbone_for_the_global_synthesis_of_species_diversity_in_the_angiosperm_order_ Caryophyllales.

IPNI (International Plant Names Index) (2010, 2011, 2012) [utilized for author names for all other plant species mentioned besides $M$. expansa] frequently downloaded from: http://www.ipni.org/index. html.

King FB (1984) Plants, people, and paleoecology; Illinois State Museum scientific papers vol XX. Illinois State Museum, Springfield, IL, Pp. ix, 134.

Kritzer Van Zant M (2016a) Analysis and development of Mirabilis expansa (Ruiz and Pav.) Standl.; For potential as a new root crop outside the Andes (Doctoral Dissertation). ProQuest Dissertations and Theses. (Accession Order No. 12694).

Kritzer Van Zant M (2016b) History of Mirabilis expansa (Ruiz and Pav.) Standl.; Growth and Use in the Andes. ATLAS J Bio doi: 10.5147, 236-248. Downloaded 31 May 2016 from: http://www. atlas-publishing.org/wp-content/uploads/2013/07/34-AJB-Van_ Zantl_2016-0138.pdf

Lawrence GHM (1951, 1970) Taxonomy of Vascular Plants. MacMillan, New York, pp. 480-481.

Linnaeus C (1737 (1968)) Hortus cliffortianus. In: J Cramer, HK. Swann (eds.) Historiae naturalis classica; Tomus LXIII. J. Cramer, Lehre, Germany, pp. 17, 53-54.

Martínez M (1969) Las plantas medicinales de Mexico edit. 5. Botas, Mexico, p. 656.

Meeker JE, JE Elias, and JA Heim (1993) Plants used by the Great Lakes Ojibwa. Great Lakes Fish and Wildlife Commission, Odanah, WI, p. 78.

Mendel, G. 1865. Experiments in plant-hybridisation; Read at the meetings of the 8th February and 8th March, 1865. In Brünn (ed) Verh. Naturf. Ver.; Abhandlungen, iv, translation by William Bateson of the Royal Horticultural Society, pp. 40-95. Downloaded Mar 21 2016 from: http://www.esp.org/books/bateson/mendel/facsimile/contents/bateson-mendel-3-peas.pdf and corrected translation by Roger Blumberg $2+39$ Pp. Downloaded 21 Mar 2016 from: http://www.esp.org/foundations/genetics/classical/gm-65.pdf.

Moerman, DE (1998) Native American ethnobotany. Timber Press, Portland, OR, pp. 359-569.

Mohlenbrock RH, and JW Voigt $(1959,1974)$ A flora of southern IIlinois. Arcturus Books Edition, Southern Illinois University Press, Carbondale, IL, p. 170.

NAPRALERT (Natural Products Alert Database) (1998) Ethnomedical information on Nyctaginaceae - 9 Jul 1998. UIC Program for Collaborative Research in the Pharmaceutical Sciences, Chicago, IL.

NCBI (2011) Taxonomy browser. Downloaded 26 Jul 2011 from: http://www.ncbi.nlm.nih.gov/Taxonomy/CommonTree/wwwcnt.cgi.

Nova (2010) A marvel of Inca engineering. Uploaded 1 Jan 2010 and downloaded Aug 25, 2015 from: http://www.pbs.org/wgbh/ nova/ancient/wright-inca-engineering.html.

Olsson G (1991) The socio-economic importance of non-timber forest products in the South Pacific: focus on Vanuatu. FAO Document Repository, Unasylva 165. Downloaded 9 Aug 2010 from: http://www. fao.org/docrep/u2440e/u2440e05.htm and 14 Mar 2016 from: http://www.fao.org/docrep/u2440e/u2440e05.htm\#the $\% 20$ socio $\% 20$ economic $\% 20$ importance $\% 20$ of $\% 20$ non $\% 20$ timber $\% 20$ forest $\% 20$ products $\% 20$ in $\% 20$ the $\% 20$ south $\% 20$ pacific.

Pelayo-Benavides HR, and AL Anaya (1993) Allelopathic potential of Mirabilis jalapa L., Nyctaginaceae (four o'clock). In: JC Schultz, I Raskin (eds.), Plant signals in interactions with other organisms, American Society of Plant Physiologists, Rockville, MD, pp. 222-223.

Popenoe H, SR King, J León, and LS Kalinowski $(1989,1990)$ Mauka. In: Vietmeyer ND (ed) Lost crops of the Incas; Little-known plants of the Andes with promise for worldwide cultivation. National Academies Press, Washington, D.C., pp. 74-81, 331. Downloaded 24 Jan 2012 from: http://www.nap.edu/openbook/030904264X/html/'74,html [download not still available], downloaded 29 Feb 2012 from: www.nap.edu/openbook.php? record_id $=1398 \&$ page $=74$.

Ray J (1682) Methodus plantarum nova: brevitatis \& perspicuitatis causa synoptice in tabulis exhibita,.... Faitborne \& Kersey, London, pp. 67-68, 112. Downloaded 19 Sep 2010 from: http://www.biodiversitylibrary.org/bibliography/37647.

Roberts, H.F. 1929. Plant hybridization before Mendel. Oxford University Press, London, Pp. 20, 38, 48, 50, 53, 58, 126, 208, 224, 337. 
Downloaded Mar21-2016 from: http://www.archive.org/stream/ planthybridizatiOOrobe/planthybridizatiOOrobe_divu.txt.

Ruiz H (1777-1788 (1940)) Travels of Ruiz, Pavón, and Dombey in Peru and Chile. Field Mus. Nat. Hist., Bot. Ser. Publication 467, 21 : 66-353.

Schaacke, S, C Gilbert and C Feschotte (2010) Promiscuous DNA: Horizontal Transfer of Transposable Elements and Why It Matters for Eukaryotic Evolution. Trends Ecol Evol 25(9): 537-546.

Showalter HM (1934) Self Flower-color Inheritance and Mutation in Mirabilis jalapa L., Genetics 19: 568-580.

Smith HH (1932) Ethnobotany of the Ojibwe Indians. Bull. Public Museum Milwaukee 4(2): 46-77.

Spellenberg RW (2006) 7. Mirabilis. In: Flora of North America Editorial Committee (eds.) Flora of North America north of Mexico. Oxford, vol. 4, pp. 14-16, 25, 40, 46-47, 50, 52. Downloaded 18 Mar 2006 from: http://www.efloras.org/florataxon.aspx?flora id=1 \&taxon_id $=12078$.

Sperling CR, and SR King (1990) Andean tuber crops: worldwide potential. In: J Janick, JE Simon (eds.) Advances in new crops. Timber Press, Portland, OR, pp. 428-435. Downloaded 17 Oct 2001 from: http://newcrop.hort.purdue.edu/newcrop/proceedings 1990/VI428.html.

Standley PC (1911) The Allioniaceae of Mexico and Central America. Contr. U.S. Natl Herbarium 13(1 1): 377-430.

Stemmerik JF (1964) Florae Malesianae Precursores XXXVIII Notes on Pisonia L. in the Old World (Nyctaginaceae). Blumea 12(2): 275 284.

Strike SS (1994) Ethnobotany of the California Indians volume 2; Aboriginal uses of California's indigenous plants. Koeltz Scientific Books, Champaign, IL, USA, p. 93.

Torrence R, and H Barton (eds.) 2006. Ancient Starch Research. Left Coast Press, Walnut Creek, CA, 256 Pp.

Tpompo (2012) Machu Picchu. University of Ceramic Tile and Stone. uploaded 18 June 2012. Downloaded 25 Aug, 2015 from: http:// uofcts.org/2012/06/machu-picchu/.

Ugent D, and LW Peterson (1988) Archeological Remains of Potato and
Sweet Potato in Peru. CIP Circular 16(3): 1-10.

Ugent D, and LS Cummings (2004) Ethnobotanical Leaflets Starch Research Page. updated 14 Apr 2004. Downloaded 4 Aug 2011 from: http://www.siu.edu/web/amylose.htm.

Ugent D, and C Ochoa (2006) La etnobotánica del Perú: desde la prehistoria al presente. Consejo Nacional de Ciencia, Tecnología e Innovación Tecnológica, CONCYTEC, Lima, Perú, pp. 403.

Ugent D, S Pozorski, and T Pozorski (1986) Archaeological Manioc (Manihot) from Coastal Peru. Economic Botany 401(1): 78-102.

Vepachedu R, HP Bais, JM Vivanco (2003) Molecular Characterization and Post-Transcriptional Regulation of ME1, a Type I Ribosomeinactivating Protein from M. expansa. Planta 217 (3): 498-506.

Vepachedu R, SW Park, N Sharma, and JM Vivanco (2005) Bacterial Expression and Enzymatic Activity Analysis of MEl, a Ribosome-inactivating Protein from Mirabilis expansa. Protein Expres Purif 40(1): 142-151.

Vivanco JM, D Weitzel, and HE Flores (1997) Characterization of a major storage root protein isolated from the Andean root crop species Mirabilis expansa. In HE Flores, JP Lynch, D Eissenstat (eds.), Radical biology: advances and perspectives on the function of plant roots. American Society of Plant Physiologists, pp. 454-457.

Vivanco JM, BJ Savary, and HE Flores (1999a) Characterization of Two Novel Type I Ribosome-inactivating Proteins from the Storage Roots of the Andean Crop Species Mirabilis expansa. Plant Physiol 119 : 1447-1456.

Vivanco JM, LF Salazar, and M Querci (1999b) Antiviral and Antiviroid Activity of MAP-containing Extracts from Mirabilis jalapa Roots. Plant Dis 83: 111 6-1121.

Vivanco JM, and HE Flores (2000) Biosynthesis of Ribosome Inactivating Proteins from Callus and Cell Suspension Cultures from Mirabilis expansa. Plant Cell Rep 19: 1033-1039.

Walker EH (1976) Flora of Okinawa and the southern Ryuku Islands; Publication \#5140. Port City Press for Smithsonian Institution Press, Washington, D.C., pp. 444-446.

Watson S (1871) Botany [Fortieth Parallel]. Engineer Department, U.S. Army, pp. 283-288, t.31, 32. 